\title{
Information Management Tools for the Development of Self-Regulated Learning Skills in Pre-service Teacher Education
}

Herramientas de gestión de la información para el desarrollo de las habilidades de aprendizaje autorregulado en la formación inicial del profesorado

\author{
Adolfina Pérez \\ Universitat de les Illes Balears \\ fina.perez@uib.es \\ Victoria I. Marín \\ Universitat de les Illes Balears \\ victoria.marin@uib.es \\ Gemma Tur \\ Universitat de les Illes Balears \\ gemma.tur@uib.es
}

Fecha presentación: 12/03/2018 | Aceptación: 11/06/2018 |Publicación: 21/12/2018

\begin{abstract}
Resumen
Este artículo presenta una estrategia didáctica para desarrollar los entornos personales de aprendizaje (PLEs) de los estudiantes universitarios con un enfoque de aprendizaje autorregulado (SRL). La estrategia se enmarca en el modelo de Dabbagh y Kitsantas (2012) que conecta las fases de aprendizaje autorregulado de Zimmerman (planificación, realización, auto-reflexión) y tres niveles de interacción que la tecnología permite (gestión personal de la información, interacción social y colaboración, recuperación y gestión de información). La estrategia se implementa con 241 estudiantes de tercer curso del Grado de Educación Primaria de la Universidad de las Islas Baleares. Los datos se recogen mediante la aplicación de un cuestionario sobre el uso de la tecnología y las percepciones de los estudiantes sobre la efectividad de las herramientas utilizadas en la de gestión de información. El análisis de los resultados permite esbozar algunos patrones en el uso de herramientas de gestión de la información en los diversos escenarios de aprendizaje. En las conclusiones identificamos desafíos relacionados con la resistencia de los estudiantes y el enfoque para la evaluación tradicional; destacamos posibilidades de transferencia de los procesos de gestión de información desarrollados a otros contextos y sugerimos nuevas implementaciones educativas y de investigación. Con este trabajo se aporta un modelo aplicable a otros contextos y se presenta una propuesta didáctica para la gestión de la información basada en el PLE y el SRL.
\end{abstract}

Palabras clave: aprendizaje autorregulado (SRL); entorno personal de aprendizaje (PLE); educación superior; formación docente inicial; estrategia didáctica; herramientas TIC.

\section{Resum}

En aquest article presentem una estratègia didàctica per desenvolupar els entorns personals d'aprenentatge (PLEs) dels estudiants universitaris amb un enfocament d'aprenentatge autorregulat (SRL). L'estratègia s'emmarca en el model de Dabbagh and Kitsantas (2012) el qual connecta les fases d'aprenentatge autorregulat de Zimmerman (planificació, realització, auto-reflexió) i tres nivells d'interacció que la tecnologia permet (gestió personal de la informació, interacció social i collaboració, recuperació i gestió d'informació). L'estratègia s'implementa amb estudiants de tercer curs del Grau d'Educació Primària de la Universitat de les Illes Balears i les dades es recullen mitjançant l'aplicació d'un qüestionari sobre l'ús de la tecnologia i les percepcions dels estudiants sobre l'efectivitat de les eines utilitzades en la de gestió d'informació. L'anàlisi dels resultats permet esbossar alguns patrons en l'ús d'eines de gestió de la informació en els diversos escenaris d'aprenentatge. En les conclusions identifiquem desafiaments relacionats amb la resistència dels estudiants i l'enfocament per a l'avaluació tradicional; destaquem possibilitats de transferència dels processos de gestió d'informació desenvolupats a altres contextos i suggerim noves implementacions educatives i d'investigació. Amb aquest treball s'aporta un model aplicable a altres contextos, i es presenta una proposta didàctica per a la gestió de la informació basada en el PLE i el SRL. 
Pérez, A., Marín, V. I. \&, Tur, G. (2018). Information Management Tools for the Development of Self-Regulated Learning Skills in Pre-service Teacher Education. @tic revista d'innovació educativa, 21, 31-39.

Paraules clau: aprenentatge autorregulat (SRL); entorn personal d'aprenentatge (PLE); educació superior; formació docent inicial; estratègia didàctica; eines TIC.

\begin{abstract}
This article presents a didactic strategy aimed at developing student teachers' personal learning environments (PLEs) with a self-regulated learning (SRL) approach. The strategy is framed in the Dabbagh and Kitsantas (2012) model, which relates Zimmerman' SRL cycle (forethought, performance, self-reflection) to the three levels of social media usage (personal information management, social interaction and collaboration, and information aggregation and management). A learning scenario was implemented to facilitate SRL skills through information management. The participants were 241 students of Education at the University of Balearic Islands (Spain) and data was collected through a questionnaire designed to explore tool usage and their perceptions of the effectiveness of those tools for information management tasks. Data analysis allows the observation of some patterns in the usage of information management tools in the diverse learning scenarios. In the conclusions challenges such as resistance and traditional assessment focus are identified; affordances for transferability of the acquired skills to other contexts are highlighted and further educational implementation and research are suggested. With this work, a model applicable to other contexts is provided, and a didactic strategy for the management of information based on the PLE and the SRL is presented.
\end{abstract}

Key Words: self-regulated learning (SRL); personal learning environment (PLE); higher education; pre-service teacher education; didactic strategy; ICT tools.

\section{Introduction}

The current open and flexible learning environment developed by the introduction of technology (Sang, Tondeur, Chai, and Dong, 2016) and, in particular, social media and PLEs in Higher Education (Salinas, 2013), which give students' an active role (Aguaded, López Meneses, and Alonso, 2010), implies the need to focus on students' strategies for autonomy and control of their own learning path (Marín, Negre, \& Pérez, 2014; Salinas, 2012; Cebrià, Mora and Igual, 2009) and eventually, self-regulated learning skills (Tur, Marín, Moreno, Gallardo, \& Urbina, 2016). In this way, technologyenhanced learning supports self-regulated learning (SRL) (Nussbaumer, Dahn, Froop, Mikroyannidis, \& Albert, 2015). Technology enhances student teachers' SRL processes (Moos and Ringdal, 2012), such as metacognition, which in turn improve the SRL skills of their own future students (Kramarski and Michalsky, 2010). Personal learning environments (PLEs) are related to SRL from a pedagogical perspective, in which social media services support student-centred learning (Dabbagh and Kitsantas, 2012; Kroop, Berthold, Nussbaumer, \& Albert, 2012; Nussbaumer, Sheffel, Niemann, Kravcik \& Albert, 2012; Rahimi, van den Berg, \& Veen, 2014). PLEs align with SRL conditions (Kravcik and Klamma, 2012; Llorente, 2013), supporting a shift from institution-centred learning to autonomous learning (Johnson and Liber, 2008; Buchem, 2012).

In this study, an open learning environment was designed, based on the PLE approach, to foster students' SRL skills. Learning activities were designed to enhance students' skills in information management. In these activities, lecturers encouraged the use of social media tools in order to achieve different SRL skills. In previous studies, Marín et al. (2014) explored the construction of PLEs, and Tur et al. (2016) analysed PLEs from an SRL perspective. However, the incorporation of PLEs for students' use of information management tools in the different phases of SRL has not been done previously. Exploration of the relationship between PLE and SRL is needed in order to implement and understand their potential. Therefore, the aim of this study was to explore how students use and perceive social media as a means of managing information by designing a didactic strategy that combining the pedagogical ideas of PLEs and SRL.

\section{Theoretical Framework}

$\mathrm{SRL}$ is generally understood as learning how to learn (Mikroyannidis, Connolly, Law, Schmitz, Vieritz, Nussbaumer, Berthold, Ullrich, y Dhir, 2014, p. 148), a proactive task carried out by the learner. It is the selfdirective process by which students' mental abilities are transformed into academic skills in social contexts (Zimmerman, 2002). Thus, self-regulated learners are "metacognitively, motivationally, and behaviorally" active (Zimmerman, 1990, p. 4) to accomplish their goals (Zimmerman, 2002).

Zimmerman (2002) describes SRL as a cycle of three phases: forethought, performance and self-reflection. These phases refer to what was done before, during and after learning, respectively. The first phase involves task analysis and self-motivation beliefs; the second, selfcontrol and observation of tasks during learning; and, the third is based on self-judgment and self-reaction. In general, other existing theories also explain the selfregulatory phases as a cycle and consider: (a) defining the task, (b) goal-setting and planning, (c) performance and (d) evaluation (van Laer and Elen, 2017). In the model by Miller and Brown (1991), the informational input is occurs during the initial phases of the learning cycle (de la Fuente, López-García, Mariano-Vera, Martínez-Vicente, \& Zapata, 2017). Previous research indicates that the more capable the student, the wider the variety of strategic tasks that the student chooses for learning (Alvi, lqbal, Masood, \& Batool, 2016). The model is cyclical because self-reflection for one learning experience can influence the forethought phase of future experiences. According to recent research, it is paramount to explore students' online self-regulated skills (Lin, Liang, Tsai, \& Hu, 2018; McLoughlin and Lee, 2010). In the context of PLE research, two other phases are included in this cycle. A fourth phase was suggested by Rahimi, van den Berg \& Veen, (2015), called Feeding back (applying), which involves both the teacher and the learner. The objective of the learner is to track their use of technology. Another phase addresses the technical environment that must be previously organized by the 
student (Nussbaumer, Dahn, Kroop, Mikroyannidis, \& Albert, 2015). Furthermore, some key processes for SRL were described by Dabbagh and Kitsantas (2004): goal setting, self-monitoring, self-evaluation, task-strategies, help-seeking and time-management. Numerous studies based on Zimmerman's model have been empirically conducted (Puustinen and Pulkkinen, 2001). The sociocognitive perspective of which aligns with the role of learning technologies (Kitsantas, 2013) and has been the framework of renowned designs such as that of Dabbagh and Kitsantas (2012).

According to Nussbaumer et al. (2015), there are several concepts related to SRL: metacognition, personalisation adaptation to students' characteristics, support, motivation and collaboration. Metacognition refers to the knowledge of one's own cognition and personalisation is understood as the adaptation to the learner's characteristics. Motivation and SRL are interdependent (Alvi and Gillies, 2015) since it is time-consuming and requires effort. Dabbagh and Kitsantas (2012) argued that when students engage in self-oriented cycles with teacher and peer support, they become motivated to create sustained PLEs. Collaboration involves additional skills (Nussbaumer et al., 2015) although it is not opposed to individual learning but on the contrary, complementary to it. In the context of PLE-based eportfolios, tensions between collaboration in open environments and assessment were observed (Tur and Urbina, 2016). Motivation and collaboration are implicitly promoted through the use of technology (Nussbaumer et al., 2015). Support is an important aspect for a successful approach to SRL through PLEs. In the iClass platform, a pioneering work in which SRL and PLE were related, a space for each phase was given to students in order to scaffold the corresponding cognitive processes (Türker and Zingel, 2008). However, this was considered insufficient for scaffolding, and more recently Kravcik and Klamma (2012) have demonstrated the need of balance between freedom and guidance.

Recent PLE research has explored the use of technology for SRL goals. Kroop, Berthold, Nussbaumer, \& Albert, (2012) suggest PLEs' positive impact on SRL phases through technology tools, although it had limitations for transferability due to its small sample size. Chaves, Trujillo, and López (2015) confirmed the impact on students' skills in the performance and self-reflection phases of SRL through the implementation of a didactic strategy based on both PLEs and virtual learning environments (VLES). They concluded that when VLE tools are integrated in PLE, students achieve the learning goals. At the same time, it has been observed that selfregulated learning is at the core of PLE since it is built by students themselves to meet their learning needs (Henri, Charlier and Limpens, 2009). Furthermore, SRL is necessary for lifelong learning skills and informal learning (Zimmerman, 2002), which has been argued to be enhanced through the PLE approach (Dabbagh and Kitsantas, 2012; García-Peñalvo, Johnson, Ribeiro, Minovic, \& Conde-González, 2014). Thus, the present study is a contribution towards the implementation of PLEs and SRL, since its implementation was carried out with a group of future primary school teachers and explores the impact of information management tools of students' PLEs in the three phases of SRL from an underresearched learning design.

Designing learning environments to foster student $\mathrm{SRL}$ is of the utmost importance (Kitsantas, 2013). Within this framework, Dabbagh and Kitsantas (2012) developed a pedagogical framework based on Zimmerman's (2002) $\mathrm{SRL}$ cycle, and on the three levels of interaction allowed by social media: personal information management, social interaction and collaboration, and information aggregation and management. They offered a model for teachers to support SRL phases through different Web 2.0 tools such as blogs, wikis, Google Calendar, YouTube, Flickr, social networking and bookmarking. At level 1, the use of social media should allow students to engage in goal-setting and planning by managing self-generated content. At level 2, the use of social media should foster collaboration and sharing, both of which are important for the self-monitoring processes in Zimmerman's performance phase. At level 3, students use social media to synthesize information from previous levels to reflect on the whole learning process. Their design promotes and supports SRL in the construction of students' PLE in a way that is "interrelated in a self-oriented system of reflective feedback" (Dabbagh and Kitsantas, 2012, p.6). Later, Kitsantas (2013) listed some examples of tools and their instructional usages for diverse processes of the SRL cycle. This interrelated model was not initially implemented (Dabbagh and Kitsantas, 2012). However, more recently some work has been done in order to explore its feasibility (Dabbagh and Kitsantas, 2013; Llorente, 2013). In this sense, this present study offers a new didactic strategy in which Zimmerman's SRL cycle is related to the three levels of social media usage by Dabbagh and Kitsantas (2012), focusing on information management tools. This is done by exploring students' use of social media and their perceptions of the effectiveness of social media tools for information management tasks and other digital artefacts, such as concept maps, and in this way adding relevant data to what is already known.

\section{Methodology and Procedure}

This study used research methodology based on Educational Design Research, consisting of a systematic analysis, design and evaluation of educational interventions in order to generating research-based solutions for complex problems in educational practice, and thus advance our knowledge of those interventions and the processes (de Benito and Salinas, 2016; Plomp, 2013). Under this research approach an educational intervention was designed based on the assumptions of PLE and SRL, and applied to student teachers studying the Degree of Primary Education at the University of Balearic Islands. Tool usage was evaluated from the point of view of the potential for the students' development of skills in the different phases of the SRL process.

A didactic process was designed which consisted of the realisation of practical projection activities aimed at the school context. This process includes the use of technology in the three levels proposed by Dabbagh and Kitsantas (2012): level 1) personal management with tools that would facilitate student planning and motivation; level 2) social interaction and collaboration; and level 3) the aggregation and management of information (see Table 1). The objective was to enable students to develop SRL in Zimmerman's (2002) three phases, plan their work, organize and manage their PLE. This methodology was implemented in the course, Media and Technological Resources for Primary Education in the academic year 2016-17, with the 241 students enrolled. These students were in their third year of their studies, and therefore had three years of experience 
Pérez, A., Marín, V. I. \&, Tur, G. (2018). Information Management Tools for the Development of Self-Regulated Learning Skills in Pre-service Teacher Education. @tic revista d'innovació educativa, 21, 31-39.

using the institutional VLE (virtual learning environment) of the university that supports face-to-face classes. In addition, according to the results of a questionnaire applied at the beginning of the course, most of them were already using the tools proposed in the didactic strategy in an academic and/or personal context.

\subsection{An SRL Didactic Strategy Related to Information Management}

The didactic strategy required the student to develop, in cooperative groups, three work projects for practical use, which must be related to a school context. The students had to create a didactic sequence using technology, a short educational video, and present best practices for the integration of technology into schools. Students had access, via the virtual classroom, to guides and support material to assist their studying and planning. This strategy promoted finding collaborative solutions to complex problems, creation of knowledge, autonomy, individual and shared responsibility, idea and concept sharing, and critical and creative thinking.

The implemented technologies within the didactic strategy included social webtools like Twitter, Pearltrees and Edmodo, as well as other tools such as CmapTools and Socrative in the institution's Moodle VLE. The students were also encouraged to use other tools as well. The selection of these tools responds to the criteria of accessibility (ease of access), functionality (ease of use and social or educational use, in its typology) and effectiveness (adequate for the learning task).

The following table represents the tools for Zimmerman' (2002) SRL cycle and Dabbagh and Kitsantas' (2012) three levels of social media usage.

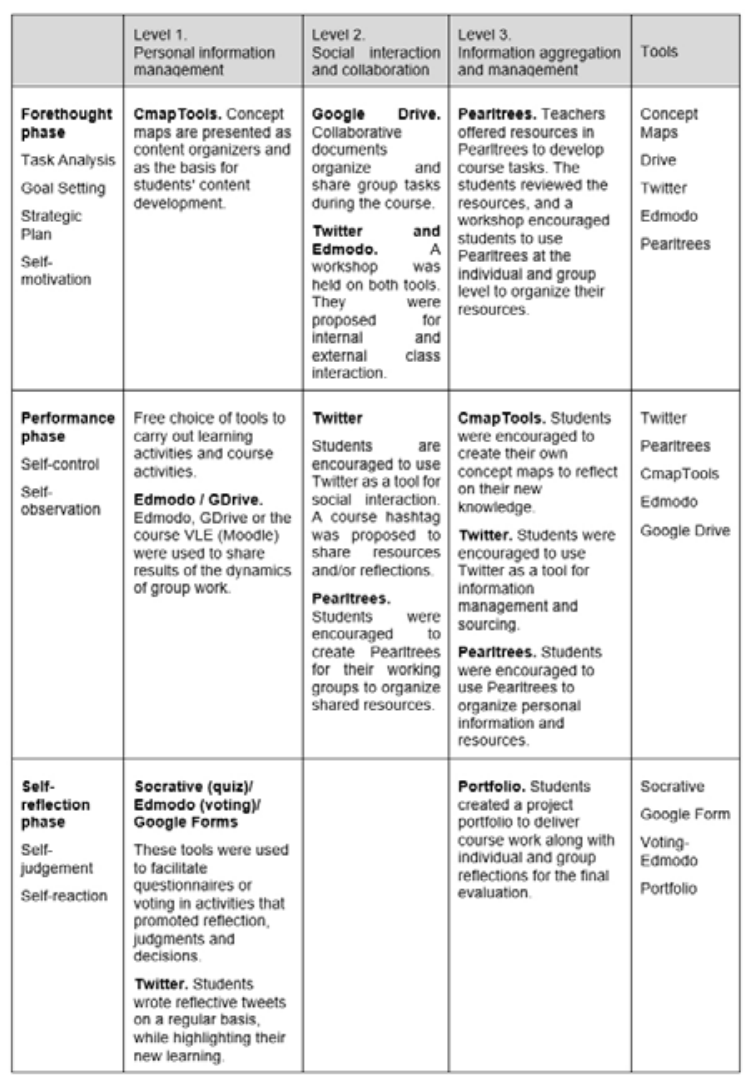

Table 1. Didactic strategy of the course based on Zimmerman's SRL cycle phases and the three levels of social media usage by Dabbagh and Kitsantas (2012).
The information management processes, which were the focus of this study, were mainly performed using three tools: CmapTools, Twitter and Pearltrees

\section{CmapTools and concept maps}

Course content was structured in multimedia concept maps with CmapTools and was available to students in their virtual classrooms. The maps presented course content in an organized and hierarchical way, offering nested enlargement resources and stating which learning activities would be developed in class. These materials provided students with a structure, or formative itinerary, that guided them in their study, organized their class participation, allowed them to include additional annotations in the maps and gave them the opportunity to create their own maps. Teachers used concept maps in face-to-face workshop sessions to present the content structure of a topic. Some of the nested resources on the map facilitated a progressively deeper learning of the topics.

\section{Pearltrees}

Teachers offered students an extensive collection of resources organized on the Pearltrees webtool. It offered students relevant and useful information sources in a simple navigation format. It also provided an example of how to organize educational web resources as future teachers and worked as a personal tool for resource management for research, organization, and sharing. A workshop introduced students to Pearltrees and encouraged its use to manage resources in the course activities.

\section{Twitter}

Twitter was used to discover information sources and create learning networks related to course topics. It also facilitated sharing relevant resources with classmates and posting reflective tweets on learning.

\subsection{Data Collection Tools}

This study's primary data collection method consisted of an online student questionnaire to assess the overall strategy of the course, resource usage and information management. The questionnaire included 20 questions, combining multiple-choice and Likert 5-item scale questions (for assessment of attitudes from total disagreement to total agreement) on the perceived value and usage of the resources offered by the teachers, and the appropriation of tools for didactic processes relating to information management. Of the 241 students, 163 participated $(68 \%)$ in the questionnaire.

No institutional arrangements for the governance of ethics exist in the country/region in which the research was conducted. However, the student questionnaire included consent for the results to be used exclusively for research purposes and the data were treated in anonymously.

\section{Results}

The didactic strategy of the course, designed to promote and support SRL in the construction of students' PLE, was evaluated favourably by the students. Questionnaire responses show that students enjoyed the strategy. They considered the course to be helpful and demonstrated that they could continue learning both professionally and personally. However, the course was not easy to follow, as shown in Figure 1. 
Pérez, A., Marín, V. I. \&, Tur, G. (2018). Information Management Tools for the Development of Self-Regulated Learning Skills in Pre-service Teacher Education. @tic revista d'innovació educativa, 21, 31-39.

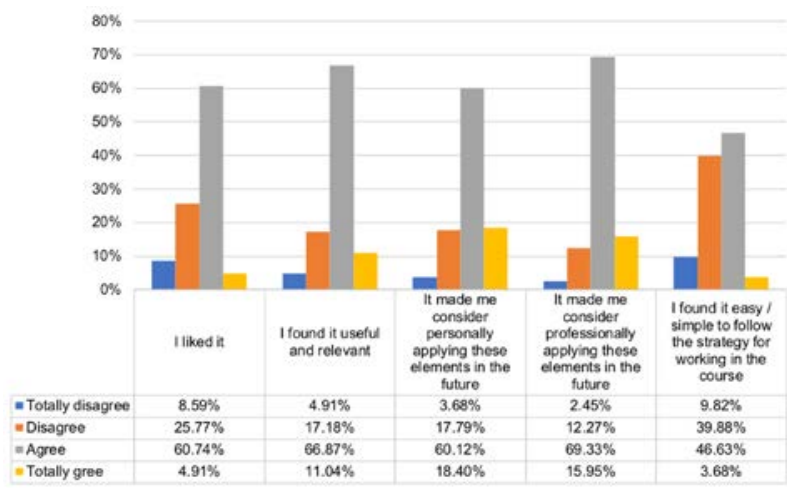

Figure 1. Assessments of didactic strategy from the questionnaire.

\subsection{Use of Resources in the Course}

In addition to the study guides, the course offered resources to facilitate student access to relevant information, such as concept maps and support resources, organized by topic in the Pearltrees webtool.

Use of concept maps

Data gathered regarding concept maps showed that $45.39 \%$ of the students used maps either enough or always. They used maps to develop their own course notes, checked maps during the class and added readings or class notes to those maps. Students often worked with maps, either as hard copies, or in PDF form. Only $15.95 \%$ of the students created their own maps (Figure 2). Concept maps were mostly utilized (Figure 3) in preparation for assessments (56.44\%) by studying the contents or supplementary documentation, rather in the preparation of classroom participation (18.4\%).

Although a majority of students were satisfied with the concept maps (55.21\%), over a third of students were not satisfied (39.26\%). This last fact was reinforced by some volunteered qualitative statements (Figure 2), which indicated that students preferred a linear presentation, rather than a map, as a basis for writing their own content.

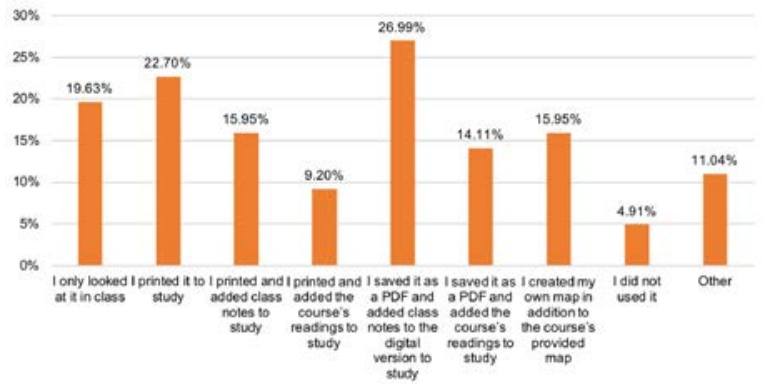

Figure 2. How students used concept maps.

Other: Half of the answers (9) highlighted the preference for writing linear notes from the maps.

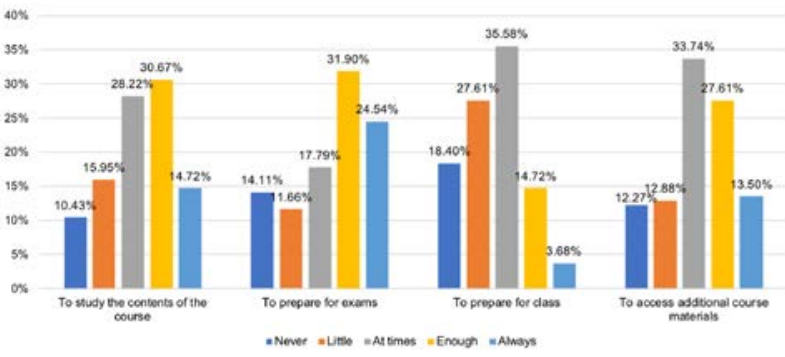

Figure 3. Students' use of concepts maps.

Use of the resources in Pearltrees as information resources

Resources placed in Pearltrees were not as well utilized as the resources in the concept maps. Students accessed these resources at times $(38.04 \%)$ or little $(28.22 \%)$ (Figure 4). These resources were used, however, for projects, with $20-30 \%$ of students has using the resources with a high frequency (always and enough), and $30 \%$ at times (Figure 5).

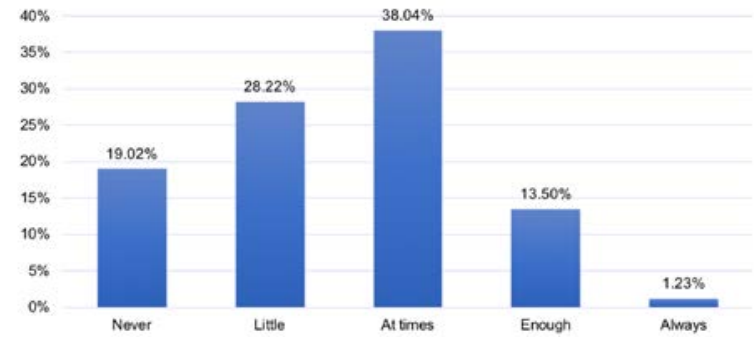

Figure 4. Level of students' use of resources selected and organized by the teachers on Pearltrees.

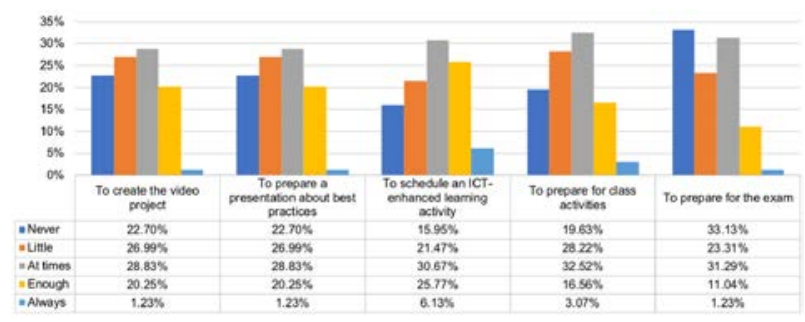

Figure 5. Students' use of resources organized on Pearltrees.

\subsection{Use of Management Information Tools}

To assess the use of tools and procedures, information on the evolution of the personal use of web 2.0 tools was collected.

Evolution of the personal use of the Pearltrees webtool Students were asked how their use of Pearltrees evolved during the course, especially after the workshop introducing the tool. The majority of students continued to use Pearltrees, and some of them (15.76\%) used it in other activities. Nearly a quarter of students said they did not create a personal Pearltrees or have not continued to use the Pearltrees created at the beginning of the course (Figure 6). In the Others option, 10 (out of 17) students claimed to have created a Pearltrees but did not use it, while 4 indicated that they used the Symbaloo tool instead to organize resources. 
Pérez, A., Marín, V. I. \&, Tur, G. (2018). Information Management Tools for the Development of Self-Regulated Learning Skills in Pre-service Teacher Education. @tic revista d'innovació educativa, 21, 31-39.

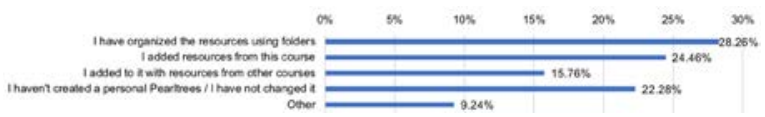

Figure 6. Evolution of personal use of the Pearltrees webtool.

Evolution of use of the Twitter tool

Students were also asked about how the use of their Twitter account evolved after the introductory workshop. Their responses reflected a high level of use of the Twitter tool for activities directly related to the course to share personal reflections, add new contacts and share resources on other topics or courses (Figure 7).

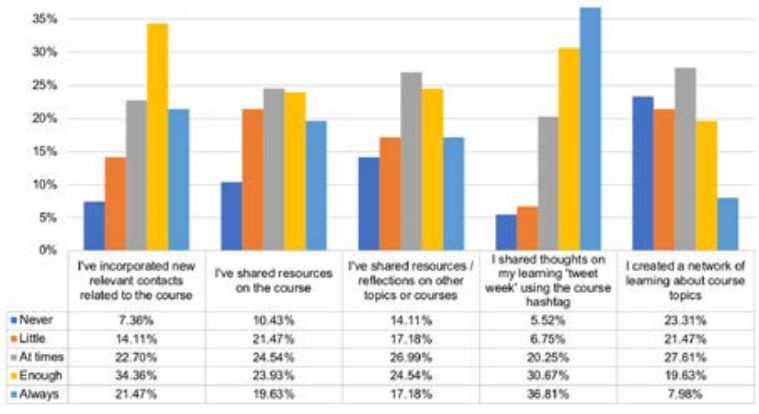

Figure 7. Evolution of personal use of Twitter.

Considering these tools in other personal or professional contexts

As shown in Figure 8, most of the students stated their intention to continue using the tools in this course in professional and/ or personal contexts.

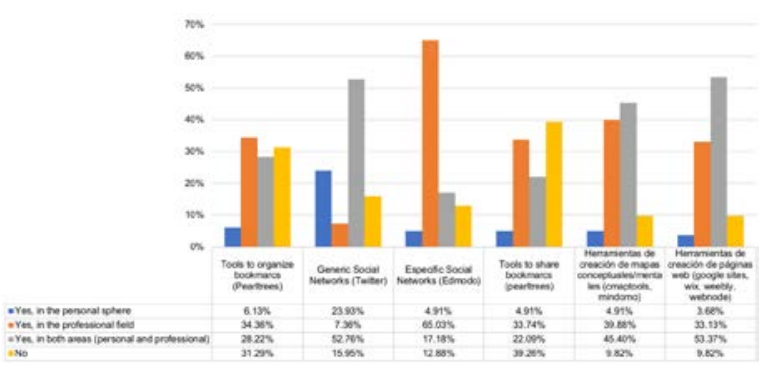

Figure 8. Future use of tools in professional or personal contexts.

Anticipated use of the didactic strategies in the future Students were asked if they believed that they would use any of the didactic strategies in the course in their immediate professional future, or in their practicum. Over $60 \%$ of students believed they would use concept maps and social networks. However, $29.45 \%$ of students were not certain about the future use of Pearltrees (Figure 9).

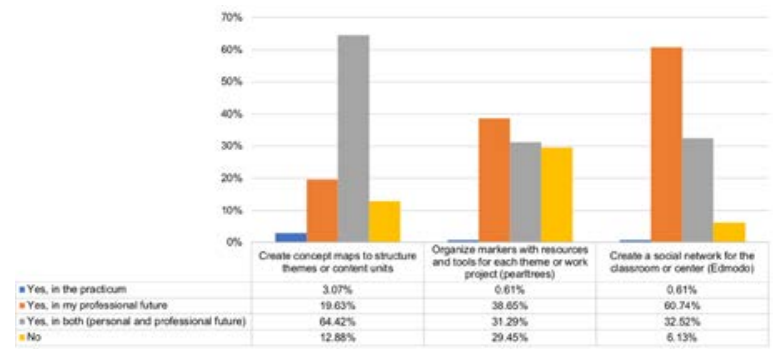

Figure 9. Anticipated use of the didactic strategies in the future.

\section{Discussion}

This study was a new step for both the educational implementation and research of the interrelated models of SRL and PLE, in line with the claim of developing student autonomy for learning (Llorente, 2012). It was an innovative learning activity in which students were encouraged to build their PLEs in cognitive, motivational and behavioural ways, following Zimmerman's (2002) model. Using social media tools for information management enhanced students' SRL phases, promoting skills for planning, monitoring and selfassessment. The didactic strategy modelled the possible implementation of diverse social media tools depending on chosen SRL processes. Also, the development of digital skills is paramount for teachers' professional growth (Cengiz, 2015). This aligns with the aim of enhancing interrelated models of PLEs and SRL for students' future professional careers.

This work explored the usage of tools based on a didactic strategy by Dabbagh and Kitsantas (2012), previously undemonstrated empirically. However, limitations from research still arise from challenges in transferability and vague conclusions from a lack of data on tools for the diverse SRL phases (Rahimi, van den Berg, and Veen, 2015). Therefore, this work represents a step forward since it explored the uses of digital tools in information management relating to the three phases of Zimmerman's (2002) SRL cycle and the model by Dabbagh and Kitsantas (2012). There are some usages of concept maps and other tools that should be specifically highlighted.

Concept maps had a range of applications. They were relevant for the forethought phase, since they were used to prepare lessons and content, although very few students created their own concept maps. However, concept maps were more widely used during assessment periods, which was only one of the learning goals presented in the course. This behaviour could mean that students thought concept maps facilitated the selfreflective phase when used as a form of self-assessment. Students may have used these maps as an instrument for studying for the exam, which would not be representative of the considered SRL skills. The fact that some students did not utilize concept maps may indicate that self-regulated usage did not meet their needs or facilitate their cognitive learning style. Furthermore, the fact that there was a greater usage of concept maps to prepare for assessments is consistent with the notetaking habits, which is more related to tests than SRL (Alvi et al., 2016).

On the other hand, Twitter received a balanced approach between the usage suggested in the didactic strategy for performance support and the self-reflective phase. Approximately half of the group frequently used Twitter to share a wide variety of resources during performance 
Pérez, A., Marín, V. I. \&, Tur, G. (2018). Information Management Tools for the Development of Self-Regulated Learning Skills in Pre-service Teacher Education. @tic revista d'innovació educativa, 21, 31-39.

phases. Most noteworthy was the students' innovative use of Twitter for self-reflection, indicating that nearly all the students used it to reflect on their own learning. However, further work is needed to explore how this reflective phase can be carried out and thus identify possible challenges. A special concern could be the possible influence of Twitter to foster self-assessment towards others' performance. Based on Zimmerman's (2002) description, this could have a negative impact on self-reflection if it emphasizes incorrect causal attributions to one's personal characteristics rather than selected learning strategies.

Finally, bookmarking (e.g. Pearltrees) and microblogging platforms (e.g. Edmodo) had a diverse role on the enhancement of SRL processes by students. Data show that students used the Pearltree resources selected by lecturers only a little, even though the didactic strategy included it in the first two phases (forethought and performance). However, they appreciated it as an information management tool and considered including it in their learning designs as future teachers. Unlike concept maps, it was used to support their performance rather than their forethought phase. Most students said they used it to carry out the performance phase, which was a high percentage considering that its use was not compulsory. The usage of Symbaloo, which was not initially included, may indicate students' resistance to new tools and may highlight the need to offer a variety of tools to explore their possibilities for SRL in future work.

\section{Conclusions}

Following the didactic strategy, student usage of information management tools revealed some patterns for SRL. In general, student use of concepts maps for the forethought phase supports planning and goal setting skills before learning. Students' greatest usage of bookmarking and microblogging services in the performance phase promotes behavioural and cognitive skills for self-recording and monitoring learning while sharing in open contexts. Microblogging in the selfreflection phase supported self-assessment skills. There were other, less significant patterns for SRL, such as using bookmarking for the forethought phase. This utilized social skills for goal settings and may have influenced students' self-efficacy beliefs. Also, the use of concepts maps in the performance phase for note-taking and study of the content may have empowered skills for self-instruction. More research is needed to collect data in greater detail on the development of motivational, cognitive and behavioural skills.

Although the didactic strategy was aimed at fostering student SRL skills, some challenges were observed in the data collection about students' usage of information and management tools in SRL processes, as stated in the previous section. These limitations can be understood as an opportunity for students to develop SRL skills, as suggested by Koivuniemi et al. (2017). Further research should include challenges, both in didactic strategy and related research. Also, future work could explore whether the low impact of information management tools is a consequence of technical difficulties while using the tool or there are other factors to be considered.

Finally, beyond pre-and in-service teachers' education, this study is of great potential for interprofessional transferability, since it has implications for online selfregulated learning in other fields and contexts. The descriptive exploration of data allows us to observe students' performance and may be informative for future design iterations and implementations at all educational levels. Moreover, preparing students for digital collaboration can be yet another positive outcome of this study since novice teachers face difficulty in finding support in the first stages of their professional practice. Thus, further research could explore if the interrelated design of SRL and PLE is a powerful tool in helping students to overcome a wide variety of challenges raised in new learning environments enhanced by technology.

\section{References}

Aguaded, I.; López Meneses, E., \& Alonso, L. (2010). Formación del profesorado y software social. Estudios sobre Educación, 18, 97-114. Retrieved from

http://www.unav.edu/publicaciones/revistas/index.p hp/estudios-sobre-educacion/article/view/4655

Alvi, E., Iqbal, Z., Masood, F., \& Batool, T. (2016). A qualitative account of the nature and use of selfregulated learning (SRL) strategies employed by university students. Australian Journal of Teacher Education, 41(8), 40-59. http://doi.org/10.14221/ajte.2016v41n8.3

Buchem, I. (2012). Psychological Ownership and Personal Learning Environments. Do possession and control really matter? Proceedings of the PLE Conference 2012, Aveiro, Portugal. Retrieved 1 March 2014 from http://revistas.ua.pt/index.php/ple/article/viewFile/1 $437 / 1323$

Castañeda, L., \& Adell, J. (2013). La anatomía de los PLEs. En L. Castañeda \& J. Adell (Eds.), Entornos Personales de Aprendizaje: Claves para el ecosistema educativo en red (pp. 11-27). Alcoy: Marfil. Retrieved from http://digitum.um.es/xmlui/bitstream/10201/30408/ 1/capitulo1.pdf

Cebrià, M.A., Mora, E.R. \& Igual,C. (2009). Use of ICT in the Autonomous Learning Process: A Case Study in Cardiocirculatory Physiotherapy. @tic revista d'innovació educativa, 3, 62-66. https://doi.org/10.7203/attic.3.154

Cengiz, C. (2015). The development of TPACK, Technology Integrated Self-Efficacy and Instructional Technology Outcome Expectations of pre-service physical education teachers. AsiaPacific Journal of Teacher Education, 43(5), 411422.

https://doi.org/10.1080/1359866X.2014.932332

Chaves, E., Trujillo, J. M., \& López, J. A. (2015). Autorregulación del Aprendizaje en Entornos Personales de Aprendizaje en el Grado de Educación Primaria de la Universidad de Granada, España. Formación Universitaria, 8(4), 63-76. https://doi.org/10.4067/S071850062015000400008

Dabbagh, N., \& Kitsantas, A. (2004). Supporting Selfregulation in student-centered web-based learning environments. International Journal on e-Learning, $3(1)$, 40-47. Retrieved from https://www.learntechlib.org/p/4104

Dabbagh, N., \& Kitsantas, A. (2012). Personal 
Pérez, A., Marín, V. I. \&, Tur, G. (2018). Information Management Tools for the Development of Self-Regulated Learning Skills in Pre-service Teacher Education. @tic revista d'innovació educativa, 21, 31-39.

Learning Environments, social media, and self regulated learning: A natural formula for connecting formal and informal learning. The Internet and Higher Education, 15(1), 3-8. https://doi.org/10.1016/j.iheduc.2011.06.002

Dabbagh, N., \& Kitsantas, A. (2013). The role of social media in self-regulated learning. International Journal of Web Based Communities, 9(2), 256273. https://doi.org/10.1504/IJWBC.2013.053248

de Benito, B., \& Salinas, J. M. (2016). La Investigación Basada en Diseño en Tecnología Educativa. Revista Interuniversitaria de Investigación en Tecnología Educativa, 0(0), 1-16. https://doi.org/10.6018/riite2016/260631

de la Fuente, J., López-García, M., Mariano-Vera, M., Martínez-Vicente, J., \& Zapata, L. (2017). Personal Self-Regulation, Learning Approaches, Resilience and Test Anxiety in Psychology Students. Estudios sobre Educación, 32, 9-26. http://dx.doi.org/10.15581/004.32.9-26

García-Peñalvo, F.J., Johnson, M., Ribeiro, G., Minovic, M., \& Conde-González, M.A. (2013). Informal learning recognition through a cloud ecosystem. Future Generation Computer Systems, 32, http://dx.doi.org/10.1016/j.future.2013.08.004

Henri, F., Charlier, B., \& Limpens, F. (2009). Understanding and Supporting the Creation of More Effective PLE. In Proceedings of the International Conference on Information Resources Management (CONF-IRM) 2009, 21st 23th May 2009, Dubai, United Arab Emirates. Retrieved http://aisel.aisnet.org/confirm2009/23

Johnson, M., \& Liber, L. (2008). The Personal Learning Environment and the human condition: from theory to teaching practice. Interactive Learning Environments, 16(1), 3-15. http://dx.doi.org/10.1080/10494820701772652

Kitsantas, A. (2013). Fostering college students' selfregulated learning with learning technologies. Hellenic Journal of Psychology, 10, 235-252. Retrieved http://psycnet.apa.org/record/2014-20467-005

Koivuniemi, M., Panadero, E., Malmberg, J., \& Järvelä, S. (2017). Higher education students' learning challenges and regulatory skills in different learning situations/Desafíos de aprendizaje y habilidades de regulación en distintas situaciones de aprendizaje en estudiantes de educación superior. Infancia y Aprendizaje, 4(1), 19-55. http://dx.doi.org/10.1080/02103702.2016.1272874

Kramarski, B., \& Michalsky, T. (2010). Preparing preservice teachers for self-regulated learning in the context of technological pedagogical content knowledge. Learning and Instruction, 20(5), 434447. http://dx.doi.org/10.1016/j.learninstruc.2009.05.003

Kravcik, M., \& Klamma, R. (2012), Supporting selfregulation by Personal Learning Environments. In
I. Aedo, R.-M. Bottino, N.-S. Chen, C. Giovannella, D. G. Sampson \& Kinshuk (Eds.), Proceedings of 12th IEEE International Conference on Advanced Learning Technologies (pp. 710-711). Rome: IEEE Computer Society. Retrieved from https://ieeexplore.ieee.org/document/6268230

Kroop, S., Berthold, M., Nussbaumer, A., \& Albert, D. (2012). Supporting Self-Regulated Learning in Personalised Learning Environments. In 1st International Workshop on Cloud Education Environments (WCLOUD 2012), 15th -16th November 2012, Antigua, Guatemala. Retrieved from http://ceur-ws.org/Vol-945/paper10.pdf

Lin, X.-F., Liang, J.-C., Tsai, C.-C., \& Hu, Q. (2018). The moderating role of self-regulated learning in job characteristics and attitudes towards webbased continuing learning in the airlines workplace. Australasian Journal of Educational Technology, 34(1), 102-115. https://doi.org/10.14742/ajet.3198

Llorente, M. (2012). e-Learning 2.0: from technology to methodology. @tic revista d'innovació educativa, 9, 79-86. https://doi.org/10.7203/attic.9.1939

Llorente Cejudo, M. C. (2013). Aprendizaje autorregulado y PLE. EDMETIC, 2(1), 58-75. https://doi.org/10.21071/edmetic.v2i1.2861

Lombaerts, K., De Backer, F., Engels, N., Van Braak, J., \& Athanasou, J. (2009) Development of the self-regulated learning teacher belief scale'. European Journal of Psychology of Education, 24(1), 79-96. https://doi.org/10.1007/BF03173476

Marín, V. I., Negre F., \& Pérez Garcias A. (2014). Entornos y redes personales de aprendizaje (PLEPLN) para el aprendizaje colaborativo [Construction of the Foundations of the PLE and PLN for Collaborative Learning]. Comunicar, 42. https://doi.org/10.3916/C42-2014-03

McLoughlin, C., \& Lee, M. J. W. (2010). Personalised and Self Regulated Learning in the Web 2.0 Era: International Exemplars of Innovative Pedagogy Using Social Software. Australasian Journal of Educational Technology, 26(1), 28-43. https://doi.org/10.14742/ajet.1100

Mikroyannidis, A., Connolly, T., Law, E.L-C., Schmitz, H-C., Vieritz, H., Nussbaumer, A., Berthold, M., Ullrich, C., \& Dhir, A. (2014). Self-regulated Learning in Formal Education: Perceptions, Challenges and Opportunities. Int. J. Technology Enhanced Learning, 6(2), 145-163. http://dx.doi.org/10.1504/IJTEL.2014.066860

Moos, D. C., \& Ringdal, A. (2012). Self-Regulated Learning in the Classroom: A Literature Review on the Teacher's Role. Education Research International, Article ID 423284. http://dx.doi.org/10.1155/2012/423284

Nussbaumer, A., Dahn, I., Kroop, S., Mikroyannidis, A., \& Albert, D. (2015). Supporting Self-Regulated Learning. In S. Kroop et al. (eds.), Responsive Open Learning Environments (pp. 17-48). http://dx.doi.org/10.1007/978-3-319-02399-1_2

Nussbaumer, A., Sheffel, M., Niemann, K., Kravcik, M., \& Albert, D. (2012). Detecting and reflecting 
Pérez, A., Marín, V. I. \&, Tur, G. (2018). Information Management Tools for the Development of Self-Regulated Learning Skills in Pre-service Teacher Education. @tic revista d'innovació educativa, 21, 31-39.

learning activities in Personal Learning Environments. Proceedings of the 2nd Workshop on Awareness and Reflection in TechnologyEnhanced Learning. Saarbrucken, Germany. Retrieved from http://dbis.rwthaachen.de/cms/publications/paper.2012-0924.5781480577?set_language $=$ de \&cl=de

Plomp, T. (2013). Educational Design Research: An Introduction. In T. Plomp \& N. Nieveen (Eds.) Educational Design Research. Part A: An Introduction pp. 10-51. Retrieved from http://international.slo.nl/publications/edr/

Puustinen, M., \& Pulkkinen, L. (2001). Models of SelfRegulated Learning: A Review. Scandinavian Journal of Educational Research, 45(3), 269-286. http://dx.doi.org/10.1080/00313830120074206

Rahimi, E., van den Berg, J., \& Veen, W. (2015). A Learning Model for Enhancing the Student's Control in Educational Process Using Web 2.0 Personal Learning Environments. British Journal of Educational Technology, 46(4), 780-792. https://doi.org/10.1111/bjet.12170

Salinas, J. (2012). La investigación ante los desafíos de los escenarios de aprendizaje futuros. Red, 32. Retrieved http://www.um.es/ead/red/32/salinas.pdf

Salinas, J. (2013). Enseñanza flexible y aprendizaje abierto, fundamentos clave de los PLEs. En L. Castañeda y J. Adell (Eds.), Entornos Personales de Aprendizaje: Claves para el ecosistema educativo en red, 53-70. Alcoy: Marfil.

Sang, G., Tondeur, J.,Chai, C. S., \& Dong, Y. (2016). Validation and Profile of Chinese Pre-service Teachers' Technological Pedagogical Content Knowledge Scale. Asia-Pacific Journal of Teacher Education, 49(1), 49-65. https://doi.org/10.1080/1359866X.2014.960800

Tur, G, Marín, V.I., Moreno, J., Gallardo, A., \& Urbina, S. (2016). From Diagrams to Self-regulated Learning: Student Teachers' Reflections on the
Construction of their PLE. Educational Media International, $\quad 53(2), \quad 139-152$. https://doi.org/10.1080/09523987.2016.1211335

Tur, G., \& Urbina, S. (2016). Collaboration in ePortfolios with Web 2.0 tools in initial teacher training / La colaboración en eportafolios con herramientas de la Web 2.0. en la formación docente inicial. Cultura y Educación, 28(3). https://doi.org/10.1080/11356405.2016.1203528

Türker, M. A., \& Zingel, S. (2008). Formative interfaces for scaffolding self-regulated learning in PLEs. elearning Papers, 9. Retrieved from http://www.citeulike.org/user/toanuzzo/article/8922 639

van Laer, S., \& Elen, J. (2017). In search of attributes that support self-regulation in blended learning environments. Education and Information Technologies, 22(4), 1395-1454. https://doi.org/10.1007/s10639-016-9505-X

Zimmerman, B. J. (1990). Self-regulated learning and academic achievement: An overview. Educational Psychologist, 25(1), 3-17. https://doi.org/10.1207/s15326985ep2501_2

Zimmerman, B. J. (2002). Becoming a self-regulated learner: An overview. Theory Into Practice, 41(2), 64-70. https://doi.org/10.1207/s15430421tip4102_2

| Cita recomendada de este artículo

Pérez, A., Marín, V. I., \& Tur, G. (2018). Information Management Tools for the Development of Self-Regulated Learning Skills in Pre-service Teacher Education. @tic revista d'innovació educativa, 21, 31-39.

https://doi.org/10.7203/attic.21.12134 